Karina LeKsy, Alina DWORAK

Uniwersytet Ślaski

w Katowicach

\title{
POSSIBILITIES OF SHAPING HEALTH-SEEKING BEHAVIOURS AMONG CHILDREN AND TEENAGERS OF THE “DIGITAL NATIVES" GENERATION
}

\begin{abstract}
Leksy Karina, Dworak Alina, Possibilities of Shaping Health-Seeking Behaviours Among Children and Teenagers of the "Digital Natives" Generation [Możliwości kształtowania zachowań prozdrowotnych wśród dzieci i młodzieży pokolenia „Digital Natives”]. Studia Edukacyjne nr 50, 2018, Poznań 2018, pp. 515-534 Adam Mickiewicz University Press. ISSN 1233-6688. DOI: 10.14746/ se.2018.50.33
\end{abstract}

\begin{abstract}
Regardless of how the contemporary young generation is described, there is no doubt that their permanent connection to the Internet and an incredible expertise in using information and communication technologies are one of the features that define those who grow up at the present time. Such strong involvement in digital media entails a number of health and development consequences for children and teenagers. In order to minimize the potential risks and negative effects of new media, it is essential to take action aimed at increasing awareness in terms of positive and negative aspects of using digital devices as well as at gaining abilities to use them in a way that is the most optimal and favourable for health. Currently, this issue constitutes a great challenge for teachers, parents, and carers for whom implementing health-seeking attitudes and behaviours of the young generation may be, taking into consideration the attractiveness of electronic media and virtual world, an enormously difficult task.
\end{abstract}

Key words: Generation C, digital natives, information and communication technologies, health-seeking behaviours, health education

Social sciences, as Piotr Sztompka writes, are always a kind of reflection of the society which they concern. Although many times they present a slightly delayed or one-sided view, simultaneously, sooner or later, they react to changes that occur in the social space. ${ }^{1}$ One of such substantial changes is

${ }^{1}$ P. Sztompka, Wyobraźnia wizualna i socjologia, [In:] Fotospołeczeństwo. Antologia tekstów z socjologii wizualnej, Ed. M. Bogunia-Borowska, P. Sztompka, Kraków 2012, p. 20. 
the domination of digital technology in the life of contemporary people for whom virtual space becomes an extremely, and sometimes even the most important environment. It is not insignificant for the development of cognitive processes (visual culture) and for human social and emotional development. Thus, such issues particularly interest social educationalists because of both media unlimited possibilities for development stimulation and the threats involved. ${ }^{2}$ Therefore, "attention to prophylactic dimension of stimuli of the living environment of an individual becomes an essential task for social educationalists," ${ }^{3}$ especially with reference to the youngest generation which is committed to virtual reality to an unprecedented extent.

A generation is a category which organizes complex and multi-faceted issues of young people. According to researchers, it is a "common denominator" that enables chronological, factual, and ideological categorization of groups of people of the same age. ${ }^{4}$ The transformation of generations may be treated as "a never-ending story about continuation and change; about transmitting deep-rooted norms, values and patterns of behaviour on the one hand, and about producing individual ideas and attitudes in response to socio-economic and cultural changes on the other hand. ${ }^{5}$ Hanna Świda-Ziemba considered "the collective outlook on the world," which is formed in the period of socialization and adolescence in a given socio-cultural context, to be particularly vital for the formation of generations. Acknowledgement of the norms, values, and attitudes by the majority of a given group and a formation of a subjective generation "world" are the effect of the above-mentioned phenomenon. ${ }^{6}$ A generation is formed as a result of the attachment of a label form the outside as well as of the inner self-definition. On the one hand, the formation of a generation is conditioned by external heterogeneity, that is to say by the way it is perceived by others, and on the other hand, by who the members of the community that shares a common moment of birth feel to be, which means by the internal homogeneity. Therefore, the concept of a generation is connected with the existence of "a generation relationship - a superior degree of connection." ${ }^{7}$

${ }^{2}$ E. Marynowicz-Hetka, Pedagogika społeczna. Podręcznik akademicki, vol. 1, Warszawa 2009, p. 63; Cf. J. Izdebska, Rodzina - dziecko - telewizja. Szanse wychowawcze i zagrożenia TV, Białystok 2000.

${ }^{3}$ E. Marynowicz-Hetka, Pedagogika spoteczna, p. 63.

${ }^{4}$ B. Fatyga, Dzicy z naszej ulicy. Antropologia kultury popularnej (Second edition - revised), Warszawa 2005, p. 12-13.

${ }^{5}$ D. Hildebrandt-Wypych, Pokolenia młodzieży. Próba konceptualizacji, Przegląd Pedagogiczny, 2009, 2(10), p. 105.

${ }^{6}$ H. Świda-Ziemba, Wartości egzystencjalne młodzieży lat dziewiećdziesiatych, Warszawa 1995, p. 47-49.

7 C. Laggewie, Die '89er. Portrait einer Generation, Hamburg 1995, p. 62-65. After: D. Hildebrandt-Wypych, Pokolenia młodzieży, p. 113. 
At present, a generation is defined as "the sum of all persons of a more or less equal age that belong to a given cultural field who, on the basis of a common socio-historical situation, display similarities in terms of conduct, motivation, attitudes, and system of values." 8 In accordance with the encyclopedic definition, a generation means: "The part of population distinguished because of age: the young or the old from the other one by, more or less, the time that passes from the parents' birth to the children's birth (...). In its sociological meaning, a generation is not differed by age but above all, by the fact that groups described as the old and the young differ noticeably from each other in their attitudes, views, recognized values, aspirations, way of life, etc. It is less about the differences that result from dissimilarities of the permanent social roles or psychological predispositions that are biologically conditioned, and more about the differences whose source are different experiences (the so-called common generation experiences) and life prospects." ${ }^{\prime 9}$ Among various definitions of the analyzed concept, Maria Ossowska recognizes the one that describes generation as "a group of people with common attitudes which are determined by shared historical experiences that have a significant influence on specific formation of individual and social character of a human being" as crucially important. ${ }^{10}$

In its traditional understanding, "generation" meant a span of 20-25 years which was marked with important and remarkable events ${ }^{11}$ and hence the following generations were hierarchically distinguished:

- the Weterans - people born between 1922 and 1945;

- the Baby Boomers - people born between 1946 and 1964;

- Generation X - people born between 1965 and 1979;

- Generation Y - people born between 1980 and 2000;

- Generation Z - people born after 2000. ${ }^{12}$

${ }^{8}$ H.M. Griese, Socjologiczne teorie młodzieży. Wprowadzenie, Trans. J. Dąbrowski, Kraków 1996, p. 80.

9 Encyklopedia PWN, Warszawa 1999. After: E. Karmolińska-Jagodzik, Komunikacja międzypokoleniowa - rozważania wokót różnic kulturowych, Studia Edukacyjne, 2012, 21, p. 192-193.

${ }^{10}$ After: E. Wysocka, Doświadczanie życia w młodości - problemy, kryzysy i strategie ich rozwiązywania, Katowice 2010, p. 163.

${ }^{11}$ J. Morbitzer, Edukacja medialna (małego) dziecka, [In:] Małe dzieci w świecie technologii informacyjno-komunikacyjnych. Pomiędzy utopijnymi szansami a przesadzonymi zagrożeniami, Ed. J. Pyżalski, Łódź 2017, p. 206.

${ }_{12}$ H. Brotheim, Introducing Generation Z, American Jails, 2014, November/December, p. 16, http:/ / eds.b.ebscohost.com.00008emw147c.han.bg.us.edu.pl/eds/pdfviewer/pdfviewer?vid $=2 \&$ sid $=$ ccf954fcaf88-4bc6-a914-a477d2edd28a\%40sessionmgr103 [access: 27. Oct. 2017]; Cf. S. Puiu, Generation Z - a new type of consumers, Young Economists Journal/Revista Tinerilor Economisti, 2016, 13, 27, p. 67, http://eds.b.ebscohost.com.00008emw147c.han.bg.us. edu.pl/eds / pdfviewer/pdfviewer?vid=4\&sid=ccf954fcaf88-4bc6-a914-a477d2edd28a\%40sessionmgr103 [access: 27. Oct. 2017]. 
Initially, this classification was used for describing American society, however, now it is also used in other countries, including Poland. ${ }^{13}$ Here, the successive generations were variously defined, e.g. as the Generation of Columbuses, the October Generation, the March Generation, the August Generation, which are precisely determined by their objectives and specificity of historical experiences. ${ }^{14}$ The "JP2 Generation" (the John Paul II generation) which shared/shares faith and values that are related to it proclaimed by the Polish Pope also deserves a mention in the context under analysis. ${ }^{15}$ It is worth noticing that the exchange of generations, which is a natural and necessary process, may become faster in a situation of dynamic technological and socio-cultural transformations that occur in society. ${ }^{16}$ Sociologists and culture experts claim that a generation changes every two years (which nevertheless raises doubts whether the use of the concept of a generation is appropriate in this case). ${ }^{17}$ "In today's society, in which the changes in conditions of social life happen in a dramatically accelerated rhythm, a generation of children is born in a completely different cultural field than the one to which belongs the generation of their parents." ${ }^{18}$

In accordance with the above-mentioned hierarchical order of generations, the contemporary teenagers are the youth of Generation $\mathrm{Z}$, they are also sometimes referred to as the "E-Generation" in order to highlight the fact that they were born after the appearance of the Internet and online communities. ${ }^{19}$ Simultaneously, it should be noticed that many other terms referring to this generation of the young appear in both scientific and popular literature. However, most of them hint at the Internet and types of behaviour that are displayed within it. Among them, one can list: "Digital Natives," ${ }^{20}$ the Google Generation, ${ }^{21}$ the App Generation, ${ }^{22}$ the Instant Genera-

${ }^{13}$ Next generations arouse the interest not only of sociologists, but also marketing and job market specialists. They will be the future employees and consumers to whom the market offer is/will be addressed. See e.g. S. Puiu, Generation Z - a new type of consumers, p. 67-78.

${ }_{14}$ M. Ossowska, Koncepcja pokolenia, Studia Socjologiczne, 1963, 2, p. 47-51. After: E. Wysocka, Doświadczanie życia w młodości, p. 227.

${ }^{15}$ R. Wojciechowska, Pokolenie X, Y na rynku pracy, https://kariera.sgh.waw.pl/artykuly/ spoleczenstwo/pokolenie-X-y-na-rynku-pracy; [access: 2 Jan. 2018].

${ }^{16}$ H.M. Griese, Socjologiczne teorie mtodzieży, p. 80.

${ }^{17}$ J. Morbitzer, Edukacja medialna, p. 206-207.

18 P. Sztompka, Socjologia. Analiza społeczna, Kraków 2003, p. 236-237.

19 E. Wysocka, Doświadczanie życia w młodości, p. 228.

${ }^{20}$ See e.g. M. Prensky, Digital Natives, Digital Immigrants, Part. 1. On the Horizon, West Yorkshire 2001; M. Jędrzejko, D. Morańska, Cyfrowi Tubylcy. Socjopedagogiczne aspekty nowych technologii cyfrowych, Dąbrowa Górnicza - Warszawa 2013.

${ }^{21}$ See e.g. M. Spitzer, Cyfrowa demencja. W jaki sposób pozbawiamy rozumu siebie i swoje dzieci, Trans. A. Lipiński, Słupsk 2013, p. 182-185; J. Morbitzer, Edukacja medialna, p. 205.

${ }^{22}$ See e.g. K. Steinmetz, J. Sanburn, Move Over, Millennials, "Time" 2015, 12/28/186, 27/28, p. 134. http:/ /eds.b.ebscohost.com.00008emw143d.han.bg.us.edu.pl/eds/pdfviewer/ 
tion, ${ }^{23}$ and the Multitasking Generation. ${ }^{24}$ Undoubtedly, the contemporary young people who became so involved in the Web may be identified (on the basis of observation of their way of behaviour and tools that they use) as " the Thumb Tribe," "the Copy-and-Paste Generation," 25 "the Like Generation," the YouTube Generation," or "the Selfie Generation." The term "Generation C" $\mathrm{C}^{26}$ which is equivalent to permanent connection to the Internet is also worth pointing out in this context. Although contemporary teenagers may be described like this with no doubt, ${ }^{27}$ it should be kept in mind that this term refers to a broader category of people displaying specific behaviour on the Internet (above all, creating and controlling content) and being permanently connected to it ("always on" ${ }^{28}$ ) mainly via their mobile phones or smartphones. Therefore, these people become "an avalanche of consumers who are the authors of the content that creates websites." ${ }^{29}$ Accordingly, "Generation C" is not defined by date of birth, but by behaviour displayed by its members - permanent connection to the Internet, using the Internet for general-purpose, proficiency in the use of the Internet, and a deep commitment to social networking websites (Facebook, YouTube, Instagram, SnapChat, Tumblr, etc.). ${ }^{30}$ There is no doubt that particular activity on the Internet is displayed by the youngest - children and youth for whom the use of the Internet is simply a social norm these days. It is not surprising

pdfviewer?vid=4\&sid=7affba84-5b45-49e8-a40e-bc3aa9180525\%40sessionmgr104 [access: 27 . Oct. 2017].

${ }^{23}$ See e.g. E. Loveland, Instant Generation, The Journal of College Admission, 2017, 234, p. 34-38. http://eds.b.ebscohost.com.00008emw143d.han.bg.us.edu.pl/eds/pdfviewer/pdfviewer?vid=8\&sid=7affba84-5b45-49e8-a40e-bc3aa9180525\%40sessionmgr104 [access: 27 Oct. 2017].

${ }^{24}$ See e.g. http://dzieci.pl/kat,1024265,title,Pokolenie-Z-nie-warto-bronic-im-dostepudo-nowychtechnologii,wid,17461223,wiadomosc.html?smgputicaid=61a1e4 [access: 27 Oct. 2017]; M. Spitzer, Cyberchoroby. Jak cyfrowe życie rujnuje nasze zdrowie, Trans. M. Guzowska, Słupsk 2016, p. 62-74.

${ }^{25}$ Cf. J. Morbitzer, Edukacja medialna, p. 205.

${ }^{26}$ See: M. Hardey, Generation C. Content, creation, connections and choice, International Journal of Market Research, 2011, 53, 6, p. 749-770. http:/ / eds.b.ebscohost.com.00008emw147c.han. bg.us.edu.pl/eds/pdfviewer/pdfviewer?vid=7\&sid=ccf954fcaf88-4bc6-a914-a477d2edd28a\%40sessionmgr103 [access: 27 Oct. 2010]. See also: J. Morbitzer, Edukacja medialna, p. 215.

${ }^{27}$ Cf. G. Sadowski, Bezpieczna cyfrowa szkoła, "Wprost", 2017, 25, https://www.wprost.pl/ tygodnik/10060541/Bezpieczna-cyfrowa-szkola.html [access: 27 Jun. 2017].

${ }^{28}$ N. Baron, Always On, Oxford, 2008.

${ }^{29}$ M. Hardey, Generation C. Content, creation, connections and choice, p. 749-770. See also: TrendWatching, GENERATION C(ASH), TrendWatch, http://trendwatching.com/trends/ pdf/2006_12_generationcash.pdf

${ }^{30}$ That is why it is aptly pointed out that the term "generation" used with reference to people who are characterized by behaviour described above is slightly misleading since the age criterion is not the most important in this case. Cf. P. Pickett, Learn the Characteristics of Generation C, https://www.thebalance.com/who-is-generation-c-and-what-are-theyall-about-2071937 [access: 27 Oct. 2017]. 
since they have been accompanied by the virtual space "in their cognitive, leisure, and interactive activities ${ }^{\prime 13}$ from an early age and which consequently became the natural environment of their life. That is why Generation $C$ is easily equated with Generation $\mathrm{Z}$ whose representatives grow up with technology in hand since the very first day of their life, which in turn causes that the Internet, mobile phones, and social networking websites constitute an indispensable element of their everyday functioning.

Taking into account the inaccuracies in terminology that were discussed above, it seems that this dilemma is solved by the term "Digital Natives" which, as a matter of fact, is attributed by some authors to the youngest generation $(Z)$ on account of their permanent connection to the Internet and use of information technology during their whole life. ${ }^{32}$ Apart from permanent use of the Internet, "Digital Natives" are characterized by communicating through digital media (80-120 text messages daily33), having unrestricted access to the Internet (which is kept in every pocket thanks to smartphones), and permanent interacting with peers via smartphone screens ("Digital Natives" sitting in a restaurant and sending text messages to each other can be easily observed). ${ }^{34}$ Therefore, it can be stated that easy access to the Internet significantly influenced behaviour patterns of particular individuals and society. ${ }^{35}$

To confirm the tendency described above, it is worth quoting the latest statistics on the use of the Internet. According to the research carried out in 2016 by the NASK Research Institute ${ }^{36}$ on a sample of 1394 students from 55 schools ( $2^{\text {nd }}$ grades of middle school and secondary schools), $80 \%$ of the respondents used the Internet at home many times or all the time, whereas 39\% used the Internet at school. $0.7 \%$ of the respondents did not use the Internet at all. People, who spent the most time online (5 hours and more) used for this purpose their mobile phones/smartphones (31.3\%). It is obvious then that easy access to the Internet causes that teenagers use it much longer or all the time. It turns out that people who used the Internet on their laptops, in most cases, dedicated to this activity from 0 to 1 hour ( $27 \%$ of the respondents) or from 1 to 3 hours $(24 \%$ of the respondents) per day. ${ }^{37}$ The adolescents use the Internet most often for

31 A. Wrońska, R. Lange, Nastolatek jako użytkownik Internetu - społeczny wzorzec, [In:] Nastolatki wobec Internetu, Ed. M. Tanaś, Warszawa 2016, p. 15.

32 See: L. Schmidt, P. Hawkins, Children of the tech revolution, "The Sydney Morning Herald" www.smh.com.au/lifestyle/life/children-of-the-tech-revoultion-20090407-9yvt.html. After: H. Brotheim, Introducing Generation Z, American Jails, 2014, November/December, p. 16.

33 A. Lenhart, S. Campbell, K. Purcell, Teens and mobile phones, Pew Research Institute, www. pewinternet.org/2010/04/20/teens-and-mobile-phones/ [access: 18 Dec. 2017].

${ }^{34}$ H. Brotheim, Introducing Generation Z, American Jails, 2014, November/December, p. 19.

35 A. Wrońska, R. Lange, Nastolatek jako użytkownik Internetu, p. 15.

${ }^{36}$ Instytut Badawczy NASK, Raport z badania "Nastolatki wobec Internetu 3.0”, NASK, Warszawa 2017.

37 Ibidem, p. 10. 
communication, cognitive, and leisure purposes. Regarding communication, the research under analysis revealed that the respondents usually communicate with their school friends (67.7\%) and friends from outside their school (59.9\%) several times a day. At the same time, the proportion of the respondents who declare that they never communicate with their parents and teachers via the Internet amounts respectively to $56.9 \%$ and $58.7 \% .^{38}$ With regard to results that were obtained, it is not astonishing that the respondents listed respectively: using social networking services, e.g. Facebook $-78.1 \%$, staying in touch with friends (via instant messaging) $-68.7 \%$, listening to music and watching films $-68.2 \%$ as the everyday purposes of using the Internet. ${ }^{39}$ Similar results were obtained in a research on young people carried out in 2016 by the Polish Centre for Public Opinion Research (Centrum Badania Opinii Publicznej) and the Polish National Bureau for Drug Prevention (Krajowe Biuro ds. Przeciwdziałania Narkomanii) on a sample of 1724 secondary school students. ${ }^{40}$ On the basis of these results, it was concluded that almost all respondents had access to the Internet at home (99\%) and used the wireless Internet via smartphones, tablets, or laptops (in total 97\%). On average, students sampled spent online four hours a day, and at the same time, $27 \%$ (of both boys and girls) declared that they used the Internet for 4-5 hours a day. Similarly as in the research of the NASK Institute, the respondents of the research under analysis dedicated most of the time they spent online to communicating with friends and exchanging text messages $-77 \%$, listening to/downloading music $-73 \%$ and watching/downloading films/TV series $-51 \%{ }^{41}$

By reviewing statistics and American literature, it turns out that the tendencies concerning access to the Internet, patterns of online behaviour, and related characteristics and problems of the adolescents are similar on a global scale. ${ }^{42}$ However, taking into account the statistical data, it is worth paying attention to the fact that teenagers between 12-17 years of age and young adults between 18-29 years of age (in both groups 95\% of the Internet users in September 2012) are the most active Internet users in the United States. ${ }^{43}$ Moreover, according to research from 2014 and 2015 on the frequency of us-

38 Ibidem, p. 25-26.

39 Cf. ibidem, p. 21.

${ }^{40}$ See M. Feliksiak, Zainteresowania i aktywności, [In:] Konsumpcja substancji psychoaktywnych przez młodzież - Młodzież 2016, Eds. M. Grabowska, M. Gwiazda, Warszawa 2017, p. 190-202.

41 Cf. ibidem, p. 194.

42 See e.g. J.M. Twenge, Has the smartphone destroyed a generation? The Atlantic, 2017, 320, 2, p. 58-65. http://eds.a.ebscohost.com.00008eh9150a.han.bg.us.edu.pl/eds/detail/detail? vid=2\&sid=4ec7a548-3a444678a409b78357468bb2\%40sessionmgr4006\&bdata=Jmxhbmc9cGw mc210ZT11ZHMtbG12ZQ\%3d\%3d\#AN=124311558\&db=a9h [access: 3 Jan. 2018].

43 Pew Research Center, Teens and Technology 2013, http://www.pewinternet.org/files/ oldmedia/Files/Reports/2013/PIP_TeensandTechnology2013.pdf [access: 14 Dec. 2017]. 
ing the Internet by American teenagers (13-17 years of age), 92\% of them use the Internet everyday, including: almost constantly - $24 \%$, several times a day $-56 \%$, about once a day $-12 \%$. Most of the respondents $(73 \%)$ have access to the Internet via their mobile phones, especially smartphones. ${ }^{44}$

With no doubt, the great technological progress and permanent accessibility of virtual reality carry numerous consequences for "Digital Natives" ' biopsychosocial functioning and style and quality of life. Perhaps it may be stated that owing to new technologies, the process of adolescence of contemporary children and young people is characterized by a completely new and different quality which, however, may be considered in two ways - as development chances and threats, especially for the youngest Internet users. The excessive use of the Internet by the youngest should not be limited only to the negative aspects for "[...] it is a mistake to think that any technological innovation produces effects of only one type" 45 and therefore, both the positive and the negative traits of "Digital Natives/Generation $Z$ " are worth mentioning. In accordance with the source literature, among the positive aspects there are:

- openness, tolerance, respect for personal freedom and freedom of choice;

- attention to social justice and principles of democracy;

- agency/causative power, orientation to cooperation and dialogue;

- creativity, innovation, quickness of action;

- independence and autonomy in thinking and acting;

- expressiveness, the ability to express one's views;

- intelligence, faster development of cognitive functions (in comparison to previous generations);

- the ability to establish new forms of communication and human relationships;

- the ability to search for information, information management;

- very high self-esteem;

- fluency in English;

- willingness to travel, experience adventures;

- hedonism;

- using the Internet for the purpose of socialization, establishing international relations. ${ }^{47}$

${ }^{44}$ Pew Research Center, Teens, Social Media E Technology Overview 2015. Smartphones Facilitate shifts in communication landscape for teens, http:/ / www.pewinternet.org/files/2015/04/PI_TeensandTech_Update2015_0409151.pdf [access: 14 Dec. 2017].

45 N. Postman, Technopol. Triumf techniki nad kultura, Warszawa 2004, p. 16. After: J. Morbitzer, Edukacja medialna, p. 224.

${ }^{46} \mathrm{Cf}$. H. Tomaszewska, Młodzież, rówieśnicy i nowe media. Społeczne funkcje technologii komunikacyjnych w życiu nastolatków, Warszawa 2012, p. 136-137.

47 Cf. G. PrakashYadav, J. Rai, The Generation Z and their Social Media Usage: A Review and a Research Outline, Global Journal of Enterprise Information System, 2017, 9, 2, p. 110-116. 
At the same time, regardless of chances and opportunities which are provided by information technology for is users, numerous threats related to its excessive use are indicated. Among negative traits of the generation so strongly involved in virtual reality there are:

- uncritical acquirement of knowledge form the Internet, orientation to obtaining information quickly (and at the same time, sharing knowledge/ information on the Internet);

- demonstrating great need for keeping in touch with peers, but mainly via social networking websites;

- lack of patience, absent-mindedness, lower ambitions in comparison to the previous generation;

- attention deficit disorder and pocket-vibration syndrome;

- narcissism and individualism; the need for being popular which leads to spending more time on social networking websites;

- strong subordination to dominant trends and popular culture, orientation to consumerism;

- lack of a system of values;

- lack of interests and plans for the future;

- lack of sense of their own and other people's privacy;

- arrogant, controversial, and sometimes aggressive behaviour (new media are used for cyberstalking);

- addiction to new media which is the cause of psychosocial problems, depression, suicide attempts, worse school and professional achievements among young people. ${ }^{48}$

Perhaps the above-mentioned positive and negative traits of "Digital Natives" generation are only some examples but nevertheless, they seem to be sufficient to become aware of the power of new technology and its enormous influence on everyday functioning of contemporary man. The awareness of the two types of influence that electronic media have on children and teenagers is especially important to parents, teachers, and health promoters. In their positive dimension, digital tools can and should be used for developmental stimulation, making the education process more attractive, and making it easier for the disabled and people with chronic condition or developmental deficit to get an education. ${ }^{49}$ Additionally, new media can be used as a part

${ }^{48}$ Cf. H. Tomaszewska, Młodzież, rówieśnicy i nowe media, p. 136-137; H. Brotheim, Introducing Generation Z, American Jails, 2014, November/December, p. 19; G. PrakashYadav, J. Rai, The Generation Z, p. 110-116.

${ }^{49}$ Cf. K. Borzucka-Sitkiewicz, K. Leksy, ICT w edukacji, profilaktyce i terapii - przykłady dobrych praktyk, Studia Edukacyjne, 2018, 1. See also: N. Walter, Wykorzystanie technologii informacyjno-komunikacyjnych we wspomaganiu komunikowania się dziecka z niepetnosprawnościa, [In:] Świat małego dziecka. Przestrzeń instytucji, cyberprzestrzeń i inne przestrzenie dzieciństwa, Eds. H. Krauze-Sikorska, M. Klichowski, Poznań 2017, p. 369-378; M. Klichowski, T. Przybyła, Does cyberspace increase 
of preventive interventions through supporting readaptation and compensation processes. ${ }^{50}$ On the other hand, adults must keep in mind the threats and potential negative consequences of ( $a b)$ using new media by the youngest. Above all, as Ewa Marynowicz-Hetka notices, it may be assumed that electronic media will not make it easier for a child to adopt prosocial attitudes and develop relationships as they will not facilitate direct dialogue and interpersonal communication. On the contrary, they can cause the weakening of human relationships, they can also lead to loneliness and family disintegration within the emotional sphere. It happens more and more often that television, computers, or tablets "fulfill the blank which arose as a result of a child's lack of direct interactions with the loved ones, the emptiness of everyday life." ${ }^{51}$ Moreover, the phenomenon of problematic use of digital tools or even addiction to them among the adolescents is clearly visible these days. ${ }^{52}$ Even though there is no consensus among the researches examining this issue as for its essence, it usually becomes a part of the so-called behavioral addictions. ${ }^{53}$

The contemporary young generation grows up in the world of intense socio-cultural changes, one of their most important indicators is radical scientific and technological and information and communication progress. These phenomena undoubtedly determine the environment and lifestyle of the adolescents. Health-seeking behaviours, which are recognized as those which "in the light of contemporary medicine usually provoke particular (positive or negative) health effects" 54 are one of its fundamental elements. In the context of life span and its quality, it is essential to shape health-seeking behaviours which favour good state of mind and general health increasing its potential and which, at the same time, protect from risks or which help to restore health. ${ }^{55}$ With reference to "Digital Natives" Generation, it requires not only complex and multidimensional actions that promote healthy lifestyle, but also preventive actions inscribed in the field of health education, which should be a process that occurs in family and teaching environment as well as in a wider social environment at a local and then national level.

young children's numerical performance? A brief overview from the perspective of cognitive neuroscience, [In:] Ibidem, p. 425-444.

${ }^{50}$ A. Watkins, Technologie informacyjne i komunikacyjne w edukacji włączającej. Rozwój dziedziny i nowe możliwości w państwach europejskich, http:// www.europeanagency.org/publications/ereports [access: 25 Jul. 2017]

${ }^{51}$ E. Marynowicz-Hetka, Pedagogika społeczna, p. 530-531.

52 Por. M. Jędrzejko, D. Morańska, Cyfrowi Tubylcy, p. 279.

53 S. Wójcik, Zagrożenia dzieci i młodzieży w Internecie, [In:] Dzieci się licza 2017. Raport o zagrożeniach bezpieczeństwa i rozwoju dzieci w Polsce, Dziecko Krzywdzone. Teoria, badania, praktyka, 2017, 1, 16, p. 281. See also: M.Z. Jędrzejko, B.P. Rosik, M. Kowalski (Eds.), Uzależnienia behawioralne. Wybrane aspekty, Pułtusk - Warszawa 2015.

${ }_{54}$ B. Woynarowska, Edukacja zdrowotna. Podręcznik akademicki, Warszawa 2008, p. 52.

${ }^{55}$ Ibidem, p. 53. 
In the context of digital technology domination, special significance in shaping health-seeking behaviours of the youngest generation is attributed to family. Contemporary family undergoes changes towards knowledge society, which forces parents to prepare themselves for new challenges. Mass media are present in every family's life wielding influence on many everyday activities and providing its members with both real and fictional world. In the era of dynamic development of media, family constitutes the foundation of shaping appropriate child-media relations. ${ }^{56}$ The role of media in a family is conditioned by the level of pedagogical culture of parents. Family media education, which is a process of acquiring by a child desirable behaviour patterns, including patterns of using the media, should begin at an early age. Developing media competence constitutes the process of shaping educational, custodial, and cultural attitudes, and gaining and acquiring knowledge of electronic media. ${ }^{57}$ In the context of social development, it is worth noticing that children prepare themselves for living in a society in which media/interpersonal communication is and will be more and more common. Therefore, appropriate parent-child, child-media, parent-media relations should help families in acquiring skills of rational and selective use of contemporary digital goods.

Regarding shaping health-seeking behaviours among children and teenagers of the digital generation, school environment plays a crucial role. Contemporary education should make an effort to meet the needs of contemporary society and adjust to the needs and abilities of the new media generation. It is essential to educate children for media reception instead of focusing solely on learning how to operate new technologies ${ }^{58}$ As Anna Andrzejewska reports, "Contemporary school, apart from providing comprehensive development of students' personality, has to prepare them for living in the contemporary world." ${ }^{59}$ Consequently, the issue of media competence and introduction of media education as a separate curricular subject are found within the range of interests of educationalists, teachers, and politicians. Such education should supply solid knowledge and skills for children, adolescents, and parents, which would enable conscious and critical reception of media, and contribute to "appropriate reception of media and using media as tools for communicat-

\footnotetext{
${ }^{56}$ A. Andrzejewska, Dzieci i młodzież w sieci zagrożeń realnych i wirtualnych. Aspekty teoretyczne i empiryczne, Warszawa 2014, p. 250.

${ }_{57}$ J. Izdebska, Dziecko w świecie mediów elektronicznych. Teoria, badania, edukacja medialna, Bialystok 2007, p. 255-256.

${ }_{58}$ J. Dobrołowicz, Wielka potrzeba edukacji medialnej, [In:] Edukacja medialna w kształceniu wczesnoszkolnym, Ed. Z. Zbróg, Kielce 2008, p. 6.

${ }_{59}$ After: A. Andrzejewska, (Nie)bezpieczny komputer - od euforii do uzależnień, Warszawa 2008, p. 52.
} 
ing, learning, gaining, gathering, and processing information" ${ }^{\prime 60}$ It is particularly relevant to acquire media competence, which " cover a group of skills of instrumental nature which concern media management and knowledge of media influence on perceptiveness and imagination [...], thinking, creativity and reflection, and social interactions." 61

It is worth pointing out that shaping individuals that will be able to live in a information society is one of the objectives of contemporary school, work during classes should support searching, preparing, and processing information, including information coming from the sources of information and communication technologies. Contents that appear together with technological progress generate a new concept: "network thinking," which is characterized by changeability and information richness, and the student-teacher relation is enriched with the Web (online teaching). ${ }^{62}$ Consequently, together with the changes that we are experiencing, teachers' competences are also changing. Well-educated teaching staff, teachers supplied with information ${ }^{63}$ and media $^{64}$ competence, who prepare students for conscious and critical reception of media, have to steer the teaching process in a way which will cause that young generation will not be afraid of new challenges. At the same time, such teachers should have knowledge of potential threats which are brought by new technologies. Therefore, continuing education, which offers teachers an opportunity for gaining current knowledge, following information and technological progress, and sharing knowledge appropriate for current needs with their students, becomes absolutely necessary.

In preventing children and adolescents from adopting risky behaviours related to new technology, one should not forget about the prevention and education, whose effectiveness - as Krzysztof Ostaszewski states - depends on the use of scientific knowledge in practice. Risky behaviours are part of psychosocial development of children and adolescents. In this case, prevention does not mean their absolute elimination, but conveying knowledge/ information that give possibilities of achieving aims and satisfying life

${ }^{60}$ B. Krzesińska-Żach, Edukacja medialna dziecka w rodzinie - wybrane aspekty, [In:] Dziecko i media elektroniczne - nowy wymiar dzieciństwa, vol. 1, Eds. J. Izdebska, T. Sosnowski, Białystok 2005, p. 54.

61 A. Serdyński, Kompetencje informatyczno-medialne nauczyciela, Szczecin 2007, p. 40.

62 A. Andrzejewska, Dzieci i młodzież w sieci zagrożeń, p. 241-243.

${ }^{63}$ Information competence is defined as "the ability of an individual to use computer equipment skillfully, to use it suitably for their needs, including using it for work purposes." After: A. Serdyński, Kompetencje informatyczno-medialne, p. 40.

64 Wacław Strykowski perceives media competence as "a harmonious composition of knowledge, understanding, judging, and using media skilfully." After: W. Strykowski, Kompetencje medialne: pojęcie, obszary, formy ksztatcenia, [In:] Kompetencje medialne społeczeństwa wiedzy, Eds. W. Strykowski, W. Skrzydlewski, Poznań 2004, p. 33. 
needs to young generation. ${ }^{65}$ Prevention is a term that describes various actions which can be educational, therapeutic, and recreational. Appropriate prevention includes actions in the field of education, information, providing alternatives, early intervention, and health-oriented policy. ${ }^{66}$ The prevention is not a remedial action, it is of protective nature and means taking conscious actions to counteract problems and stop them from appearing. Possessing knowledge about risk factors of a particular disease/risky behaviours or health problems, which will determine the type of prevention, is the starting point for preventive actions. ${ }^{67}$

The contemporary approach to prevention departs from the negative model, which is based on prohibition and restriction, to the benefit of the positive model which is oriented to developing strong points of an individual and shaping their personal resources. Modern positive prevention should consider three elements: it should strengthen resources, improve relations with others, and influence the creation of favourable atmosphere at school or university. ${ }^{68}$ According to Zbigniew Gaś, positive approach to prevention is based on supposition, one should not only prevent symptoms, but also focus on supporting and helping people in developing their life skills and resourcefulness. ${ }^{69}$ The conception of positive prevention assumes that preventing behaviours that are risky and harmful for health should be oriented to: supporting positive development of behaviours; creating a favourable school environment; supporting parents and family; boosting young people's self-esteem; including them in social activity; developing constructive interests; developing spiritual strength, life skills and competencies which are activated in a high risk situation. ${ }^{70}$

In preventing new addictions, health promotion and health education cannot be omitted as well. Together with prevention, they are accessible to everyone and their moderate financial outlays will bring real savings to the state's budget by means of reducing costs of treatment, care, and physiotherapy. Health promotion and health education are directed to individuals, communities, and society with the aim of supporting them in health activities, including creating health-friendly environments. Simultaneously, actions for health which are carried out by health promotion programmes require appro-

${ }^{65}$ K. Ostaszewski, Edukacja w zapobieganiu zachowaniom ryzykownym, [In:] Edukacja zdrowotna, Ed. B. Woynarowska, Warszawa 2017, p. 440.

${ }^{66}$ E. Krzyżak-Szymańska, A. Szymański, Nowe wyzwania profilaktyki w kontekście zagrożeń dzieci i młodziė̇y, [In:] Zagrożenia cyberprzestrzeni i świata wirtualnego, Ed. J. Bednarek, A. Andrzejewska, Warszawa 2014, p. 199-200.

${ }_{67}$ K. Ostaszewski, Edukacja w zapobieganiu, p. 114-115.

68 N. Ogińska-Bulik, Uzależnienia od czynności. Mit czy rzeczywistość, Warszawa 2010, p. 193.

69 Z. Gaś, Profilaktyka w szkole, Warszawa 2006, p. 31.

70 After: K. Ostaszewski, Edukacja w zapobieganiu, p. 114-115. 
priate competence which is gained through health education. World Health Organization describes health education as "conscious creation of learning possibilities that include various forms of communication in order to increase health literacy, knowledge, and development of life skills which favour health of individuals and communities, health education not only provides information, but also strengthens motivation, skills, and personal effectiveness which are all essential for taking actions in favour of health." 71 From among various models and conceptions of health education, the one provided by WHO seems to be the most appropriate and possible to apply in the process of shaping health-seeking behaviours in "Digital Natives" generation. Definitions of health education highlight its essential characteristics among which one should enumerate: learning which should be understood as activity and involvement of those who participate in health education; a lifetime process, regularity of its effects and their planning; influence on both an individual and a group, on healthy and sick people in order to increase their competence; freedom of participation which is understood as acting of one's own free will and with full understanding and acceptance of activities that are taken as a part of health education; and interdisciplinary approach of health education. ${ }^{72}$

Health education aspires to change both individual behaviour and social action of people. In order to cope with it, it is necessary to change the conditioning of behaviours and actions. Therefore, the process of health education consists in modification of determinants of individual behaviours, such as knowledge of the receivers, their consciousness, beliefs, attitudes, skills, and self-efficacy. ${ }^{73}$ Educating and sensitizing young generation to threats which result from adopting harmful and risky behaviours uses information strategy by which young people gain knowledge about the effects of risky and harmful behaviours. Despite an increase of knowledge about threats resulting from behaviours that are harmful for health, a change of these behaviours was not achieved in many educational programmes. As Irena Heszen-Niejodek provides, such divergence between knowledge and inappropriate behaviours is called "a cognitive approach drama." 74 Knowledge itself, information conveyed with the use of expository methods, in which the receiver's activity is reduced to listening or watching, are not sufficient in educational action. In order to increase the effectiveness of information strategies, it is necessary to use the knowledge about conditions that are essential for shaping cogni-

${ }^{71}$ See: B. Woynarowska, Terminologia, cele i koncepcje wspótczesnej edukacji zdrowotnej, [In:] Edukacja zdrowotna, p. 96.

${ }_{72}$ B. Woynarowska, Edukacja zdrowotna - podstawy teoretyczne i metodyczne, [In:] Ibidem, p. 102-103.

${ }^{73}$ D. Cianciara, Zarys wspótczesnej promocji zdrowia, Warszawa 2010, p. 104-105.

${ }^{74}$ I. Heszen-Niejodek, Promocja zdrowia - próba systematyzacji z perspektywy psychologa, Promocja Zdrowia. Nauki Społeczne i Medyczne, 1995, 2(5-6), p. 7-21. 
tive processes which directly condition behaviour. ${ }^{75}$ Health promotion and health education that are directed to children and adolescents include crucial elements, such as developing social and cognitive skills, shaping mental toughness, and making choices that are beneficial for health. Prevention programmes aiming at reducing the risk of development of new addictions should consider issues related to experiencing emotions, stress, interpersonal skills, and skills of discovering and shaping personal resources. ${ }^{76}$

Janusz Morbitzer underlines that although people become more and more influenced by new digital technologies, it is still fundamental to invoke traditional values, positive models, and honest interpersonal relations, especially in everyday pedagogical practice, education, and socialization. Education and upbringing in digital world equals with maintaining balance between "technological and cultural aspect of the development of the charges," and being able to recognize both positive and negative aspects of the presence of adolescents in media space. ${ }^{77}$ "Thus, the art of education and upbringing at school, in a family, and any other places in which these processes occur, consists today in recognizing threats which may be caused by new technologies that enter our lives quite rapidly, and supporting making use of all chances and possibilities created by information society." ${ }^{\prime 7}$

The position of electronic media in everyday life of children and teenagers, related patterns of behaviour, and health and development consequences require taking diversified actions the essence of which would consist not so much in introducing new methods of therapy as in raising social self-awareness of new threats with simultaneous ability to shape habits of appropriate use of contemporary civilization "goods." In accordance with the rule that "prevention is better than cure," it is necessary to take early efforts that would aim at minimizing risks of excessive involvement in compulsive behaviours mainly among the young generation. Undoubtedly, preventing negative phenomena that result from improper use of digital technology requires an interdisciplinary approach on the one hand, but on the other hand it constitutes a particularly important and current challenge for contemporary educationalists, and pedagogical research and for appropriate solutions for pedagogical practice.

\section{BIBLIOGRAPHY}

Andrzejewska A., (Nie)bezpieczny komputer - od euforii do uzależnień, Wydawnictwo Akademii Pedagogiki Specjalnej, Warszawa 2008.

${ }^{75}$ K. Ostaszewski, Edukacja w zapobieganiu, p. 440-441.

${ }^{76}$ N. Ogińska-Bulik, Uzależnienia od czynności, p. 194-195.

77 J. Morbitzer, Edukacja medialna, p. 224.

${ }^{78}$ M.J. Szymański, Socjologia edukacji. Zarys problematyki, Kraków 2013, p. 136. 
Andrzejewska A., Dzieci i młodzież w sieci zagrożeń realnych i wirtualnych. Aspekty teoretyczne i empiryczne, Wydawnictwo DIFIN, Warszawa 2014.

Baron N., Always On, Oxford University Press, Oxford, 2008.

Borzucka-Sitkiewicz K., Leksy K., ICT w edukacji, profilaktyce i terapii - przykłady dobrych praktyk, Studia Edukacyjne, 2018, 1.

Brotheim H., Introducing Generation Z, "American Jails” 2014, November/December. http:/ / eds.b.ebscohost.com.00008emw147c.han.bg.us.edu.pl/eds/pdfviewer/pdfviewer?vid=2\&sid=ccf954fc-af88-4bc6-a914-a477d2edd28a\%40sessionmgr103 [access 27. Oct.2017].

Cianciara D., Zarys wspótczesnej promocji zdrowia, Wydawnictwo PZWL, Warszawa 2010.

Dobrołowicz J., Wielka potrzeba edukacji medialnej, [In:] Edukacja medialna w kształceniu wczesnoszkolnym, Ed. Z. Zbróg, Wydawnictwo Pedagogiczne ZNP, Kielce 2008.

Encykolpedia PWN, Warszawa 1999.

Fatyga B., Dzicy z naszej ulicy. Antropologia kultury popularnej (wydanie drugie poprawione), Ośrodek Badań Młodzieży, Instytut Stosowanych Nauk Społecznych, Uniwersytet Warszawski, Warszawa 2005.

Feliksiak N.M., Zainteresowania i aktywności, [In:] Konsumpcja substancji psychoaktywnych przez młodzież - Młodzież 2016, Eds. M. Grabowska, M. Gwiazda, CBOS, Krajowe Biuro ds. Przeciwdziałania Narkomanii, Warszawa 2017.

Gaś Z., Profilaktyka w szkole, Wydawnictwa Szkolne i Pedagogiczne, Warszawa 2006.

Griese H.M., Socjologiczne teorie młodzieży. Wprowadzenie, Trans. J. Dąbrowski, Oficyna Wydawnicza Impuls, Kraków 1996.

Hardey M., Generation C. Content, creation, connections and choice, International Journal of Market Research, 2011, 53, 6. http://eds.b.ebscohost.com.00008emw147c.han.bg.us. edu.pl/eds / pdfviewer / pdfviewer?vid=7\&sid=ccf954fc-af88-4bc6-a914-a477d2edd28a\%40sessionmgr103 [access: 27. Oct. 2017].

Heszen-Niejodek I., Promocja zdrowia - próba systematyzacji z perspektywy psychologa, Promocja Zdrowia. Nauki Społeczne i Medyczne, 1995, 2(5-6).

Hildebrandt-Wypych D., Pokolenia młodzieży. Próba konceptualizacji, Przegląd Pedagogiczny, 2009, 2(10).

http:/ / dzieci.pl/kat,1024265,title,Pokolenie-Z-nie-warto-bronic-im-dostepu-do-nowych -technologii,wid,17461223, wiadomosc.html?smgputicaid=61a1e4 [access: 27. Oct. 2017].

Instytutu Badawczego NASK, Raport z badania "Nastolatki wobec Internetu 3.0", NASK, Warszawa 2017.

Izdebska J., Rodzina - dziecko - telewizja. Szanse wychowawcze i zagrożenia TV, Wydawnictwo Uniwersyteckie Trans Humana, Białystok 2000.

Izdebska J., Dziecko w świecie mediów elektronicznych. Teoria, badania, edukacja medialna, Wydawnictwo Uniwersyteckie Trans Humana, Białystok 2007.

Jędrzejko M., Morańska D., Cyfrowi Tubylcy. Socjopedagogiczne aspekty nowych technologii cyfrowych, Wydawnictwo Wyższej Szkoły Biznesu w Dąbrowie Górniczej i Oficyna Wydawnicza ASPRA-JR, Dąbrowa Górnicza - Warszawa 2013.

Jędrzejko M.Z., Rosik B.P., Kowalski M. (Eds.), Uzależnienia behawioralne. Wybrane aspekty, Akademia Humanistyczna im. A. Gieysztora w Pułtusku, Oficyna Wydawnicza ASPRA-JR, Pułtusk - Warszawa 2015.

Karmolińska-Jagodzik E., Komunikacja międzypokoleniowa - rozważania wokót różnic kulturowych, Studia Edukacyjne, 2012, 21.

Klichowski M., Przybyła T., Does cyberspace increase young children's numerical performance? A brief overview from the perspective of cognitive neuroscience, [In:] Świat matego dziecka. 
Przestrzeń instytucji, cyberprzestrzeń i inne przestrzenie dzieciństwa, Eds. H. Krauze-Sikorska, M. Klichowski, Wydawnictwo Naukowe UAM, Poznań 2017.

Krzesińska-Żach B., Edukacja medialna dziecka w rodzinie - wybrane aspekty, [In:] Dziecko i media elektroniczne - nowy wymiar dzieciństwa, t. 1, Eds. J. Izdebska, T. Sosnowski, Wydawnictwo Uniwersyteckie Trans Humana, Białystok 2005.

Krzyżak-Szymańska E., Szymański A., Nowe wyzwania profilaktyki w kontekście zagrożeń dzieci i młodzieży, [In:] Zagrożenia cyberprzestrzeni i świata wirtualnego, Eds. J. Bednarek, A. Andrzejewska, Wydawnictwo Difin, Warszawa 2014.

Laggewie C., Die '89er. Portrait einer Generation, Hoffmann und Campe, Hamburg 1995.

Lenhart A., Campbell S., Purcell K., Teens and mobile phones, Pew Research Institute, www. pewinternet.org/2010/04/20/teens-and-mobile-phones/ [access: 18. Dec. 2017].

Loveland E., Instant Generation, The Journal of College Admission, 2017, Issue 234, http:/ / eds.b.ebscohost.com.00008emw143d.han.bg.us.edu.pl/eds/pdfviewer/pdfviewer?vid=8\&sid=7affba84-5b45-49e8-a40e-bc3aa9180525\%40sessionmgr104 [access: 27. Oct. 2017].

Marynowicz-Hetka E., Pedagogika społeczna. Podręcznik akademicki, vol. 2, Wydawnictwo Naukowe PWN, Warszawa 2007.

Marynowicz-Hetka E., Pedagogika społeczna. Podręcznik akademicki, vol. 1, Wydawnictwo Naukowe PWN, Warszawa 2009.

Morbitzer J., Edukacja medialna (małego) dziecka, [In:] Małe dzieci w świecie technologii informacyjno-komunikacyjnych. Pomiędzy utopijnymi szansami a przesadzonymi zagrożeniami, Ed. J. Pyżalski, Wydawnictwo „Eter”, Łódź 2017.

Ogińska-Bulik N., Uzależnienia od czynności. Mit czy rzeczywistość, Wydawnictwo Difin, Warszawa 2010.

Ossowska M., Koncepcja pokolenia, Studia Socjologiczne, 1963, 2.

Ostaszewski K., Edukacja w zapobieganiu zachowaniom ryzykownym, [In:] Edukacja zdrowotna, Ed. B. Woynarowska, Wydawnictwo Naukowe PWN, Warszawa 2017.

Pew Research Center, Teens and Technology 2013, http://www.pewinternet.org/files/ old-media/Files/Reports/2013/PIP_TeensandTechnology2013.pdf [access: 14. Dec. 2017].

Pew Research Center, Teens, Social Media \& Technology Overview 2015. Smartphones Facilitate shifts in communication landscape for teens, http://www.pewinternet.org/files/2015/04/PI_TeensandTech_Update2015_0409151.pdf [access: 14. Dec. 2017].

Pickett P., Learn the Characteristics of Generation C, https:/ / www.thebalance.com/who-isgeneration-c-and-what-are-they-all-about-2071937 [access: 27.10.2017].

Postman N., Technopol. Triumf techniki nad kultura, Warszawskie Wydawnictwo Literackie MUZA SA, Warszawa 2004.

PrakashYadav G., Rai J., The Generation Z and their Social Media Usage: A Review and a Research Outline, Global Journal of Enterprise Information System, 2017, 9, 2. http:/ / eds.a.ebscohost.com.00008eh90872.han.bg.us.edu.pl/eds/detail/detail?vid=2\&si$\mathrm{d}=7 \mathrm{~d} 0$ cdcae-e6b8-4c97-8b30-947c40dcf969\%40sessionmgr4010\&bdata=Jmxhbmc9cGwmc210ZT11ZHMtbG12ZQ\%3d\%3d\#AN=124479165\&db=bth [access: 27. Oct. 2017].

Prensky M., Digital Natives, Digital Immigrants, Part. 1. On the Horizon, MCB University Press, West Yorkshire 2001.

PuiuS., Generation Z-anew typeof consumers, ,,YoungEconomists Journal” / "Revista Tinerilor Economisti” 2016, Vol.13, Issue27, http:/ / eds.b.ebscohost.com.00008emw147c.han.bg. us.edu.pl/eds/pdfviewer/pdfviewer?vid=4\&sid=ccf954fc-af88-4bc6-a914-a477d2edd28a\%40sessionmgr103 [access: 27. Oct 2017]. 
Sadowski G., Bezpieczna cyfrowa szkoła, „Wprost” 2017, 25. https:/ / www.wprost.pl/tygodnik/10060541/Bezpieczna-cyfrowa-szkola.html [access: 27. Jun. 2017].

Schmidt L., Hawkins P., Children of the tech revolution, "The Sydney Morning Herald", www.smh.com.au/lifestyle/life/children-of-the-tech-revoultion-20090407-9yvt.html.

Serdyński A., Kompetencje informatyczno-medialne nauczyciela, Wydawnictwo Naukowe Uniwersytetu Szczecińskiego, Szczecin 2007.

Spitzer M., Cyfrowa demencja. W jaki sposób pozbawiamy rozumu siebie i swoje dzieci, Trans. A. Lipiński, Wydawnictwo Dobra Literatura, Słupsk 2013.

Spitzer M., Cyberchoroby. Jak cyfrowe życie rujnuje nasze zdrowie, Trans. M. Guzowska, Wydawnictwo Dobra Literatura, Słupsk 2016.

Steinmetz K., Sanburn J., Move Over, Millennials, „Time” 12/28/2015, vol. 186, Issue 27/28, http:/ / eds.b.ebscohost.com.00008emw143d.han.bg.us.edu.pl/eds/pdfviewer/ pdfviewer?vid=4\&sid=7affba84-5b45-49e8-a40e-bc3aa9180525\%40sessionmgr104 [access: 27. Oct. 2017].

Strykowski W., Kompetencje medialne: pojęcie, obszary, formy ksztatcenia, [In:] Kompetencje medialne społeczeństwa wiedzy, Eds. W. Strykowski, W. Skrzydlewski, Wydawnictwo eMPi2, Poznań 2004.

Sztompka P., Socjologia. Analiza społeczna, Wydawnictwo Znak, Kraków 2003.

Sztompka P., Wyobraźnia wizualna i socjologia, [In:] Fotospołeczeństwo. Antologia tekstów z socjologii wizualnej, Ed. M. Bogunia-Borowska, P. Sztompka, Wydawnictwo Znak, Kraków 2012.

Szymański M.J., Socjologia edukacji. Zarys problematyki, Oficyna Wydawnicza Impuls, Kraków 2013.

Świda-Ziemba H., Wartości egzystencjalne młodzieży lat dziewięćdziesiątych, ISNS, Uniwersytet Warszawski, Warszawa 1995.

Tomaszewska H., Młodzież, rówieśnicy i nowe media. Społeczne funkcje technologii komunikacyjnych w życiu nastolatków, Wydawnictwo Akademickie Żak, Warszawa 2012.

TrendWatching, GENERATION C(ASH), TrendWatch, http://trendwatching.com/ trends/pdf/2006_12_generationcash.pdf

Twenge J.M., Has the smartphone destroyed a generation?, The Atlantic, 2017, 320, 2, http:// eds.a.ebscohost.com.00008eh9150a.han.bg.us.edu.pl/eds/detail/detail?vid=2\&si$\mathrm{d}=4$ ec7a548-3a44-4678-a409-b78357468bb2\%40sessionmgr4006\&bdata=Jmxhbmc9cGwmc210ZT11ZHMtbGl2ZQ\%3d\%3d\#AN=124311558\&db=a9h [access: 03. Jan. 2018].

Walter N., Wykorzystanie technologii informacyjno-komunikacyjnych we wspomaganiu komunikowania się dziecka z niepetnosprawnościa, [In:] Świat małego dziecka. Przestrzeń instytucji, cyberprzestrzeń i inne przestrzenie dzieciństwa, Eds. H. Krauze-Sikorska, M. Klichowski, Wydawnictwo Naukowe UAM, Poznań 2017.

Watkins A., Technologie informacyjne i komunikacyjne w edukacji włączającej. Rozwój dziedziny i nowe możliwości w państwach europejskich, http:/ / www.europeanagency.org/publications/ereports [access: 25. Jul. 2017].

Wojciechowska R., Pokolenie X,Y na rynku pracy, https://kariera.sgh.waw.pl/artykuly/ spoleczenstwo/pokolenie-X-y-na-rynku-pracy, [access: 02. Jan. 2018].

Woynarowska B., Edukacja zdrowotna - podstawy teoretyczne i metodyczne, [In:] Edukacja zdrowotna. Podręcznik akademicki, Ed. B. Woynarowska, Wydawnictwo Naukowe PWN, Warszawa 2007.

Woynarowska B., Edukacja zdrowotna. Podręcznik akademicki, Wydawnictwo Naukowe PWN, Warszawa 2008.

Woynarowska B., Terminologia, cele i koncepcje wspótczesnej edukacji zdrowotnej, [In:] Edukacja zdrowotna, Ed. B. Woynarowska, Wydawnictwo Naukowe PWN, Warszawa 2017. 
Wójcik S., Zagrożenia dzieci i młodzieży w internecie, [In:] Dzieci się licza 2017. Raport o zagrożeniach bezpieczeństwa i rozwoju dzieci w Polsce, Fundacja Dajemy Dzieciom Siłę, Dziecko Krzywdzone. Teoria, badania, praktyka, 2017, 1, 16.

Wrońska A., Lange R., Nastolatek jako użytkownik Internetu - społeczny wzorzec konsumpcji, [In:] Nastolatki wobec Internetu, Ed. M. Tanaś, NASK, Warszawa 2016.

Wysocka E., Doświadczanie życia w młodości - problemy, kryzysy i strategie ich rozwiąywania, Wydawnictwo Uniwersytetu Śląskiego, Katowice 2010. 
